\title{
IDENTITY AMBIGUITY AND THE PROMISES AND PRACTICES OF HYBRID E- HRM PROJECT TEAMS
}

\begin{abstract}
The role of IS project team identity work in the enactment of day-to-day relationships with their internal clients is under-researched. We address this gap by examining the identity work undertaken by an electronic human resource management (e-HRM) 'hybrid' project team engaged in an enterprise-wide IS implementation for their multi-national organisation. Utilising social identity theory, we identify three distinctive, interrelated dimensions of project team identity work (project team management, team 'value propositions' (promises) and the team's 'knowledge practice'). We reveal how dissonance between two perspectives of e-HRM project identity work (clients' expected norms of project team's service and project team's expected norms of themselves) results in identity ambiguity. Our research contributions are to identity studies in the IS project management, HR and hybrid literatures and to managerial practice by challenging the assumption that hybrid experts are the panacea for problems associated with IS projects.
\end{abstract}

KEYWORDS: e-HRM; project team identity work; social identity; value propositions; knowledge practice; identity ambiguity.

Carole Tansley 1 Nottingham Business School, Nottingham Trent University, Goldsmith Street, Nottingham. NG1 4BU United Kingdom. Carole.tansley@ntu.ac.uk .[Corresponding author]. Telephone: $0044(0) 1158482415$

Jimmy Huang, Warwick Business School, The University of Warwick, Coventry, CV4 7AL, UK. Jimmy.huang@wbs.ac.uk

Carley Foster $_{3}$, Nottingham Business School, Nottingham Trent University, Goldsmith Street, Nottingham. NG1 4BU United Kingdom. carley.foster@ntu.ac.uk

\section{INTRODUCTION}

Information Systems (IS) projects invariably require team members to engage in 'hybrid' roles, that is, they are experts working on the project in more than one discipline who draw upon functional knowledge and expertise in hybrid practices and processes in order to 'make possible lateral information flows and cooperation across the boundaries of organizations, firms and groups of experts or professionals' (Miller et al., 2008, p. 943). The notion of the hybrid has been defined in a general sense as 'new phenomena produced out of two or more elements normally found separately'. Hybrids are variously identified as: 'actors, entities, objects, practices, processes and bodies of expertise' with 'distinctive and relatively stable attributes and 
characteristics, and are not merely intermediary or transitory forms' (Miller et al., 2008, p. 943).

Research on hybrids has been undertaken across disciplines, studying topics such as the changing location of accounting practices and expertise in doctors' education (Jacobs, 2005), managerial hybrids (Rees, 1996), 'hybridised' medical expertise in Finland (Kurunmäki, 2004) and the interplay between organizations and the wider structure of IS expertise (Scarborough, 1993). In this paper we focus on those hybrid project teams engaged in the implementation of electronic HRM (e-HRM) systems, which are comprised of web-based systems designed to support the implementation of human resourcing (HR) strategies, policies and practices in organizations (Ruël et al., 2004) by a variety of organizational actors (Stroehmeier, 2007).

It is important for those managing e-HRM projects to understand the hybridized context of project team members, not least because of the way potential ambiguity and fragmentation may result from the design and enactment of such projects. This is because their activities involve constant engagement in a dual hybridization process: forming and reforming at the margins of other practices and disciplines, such as information technology, human capital management and human resource planning (Tansley et al., 2001), while at the same time re-hybridizing through other encounters. The enactment of such a dynamic context can produce a serious lack of understanding of internal clients about what the project team is there to do for them, thus impacting on the client's perception of service quality, which, in turn, may negatively influence such key relationships when the pressure is on to deliver global functional strategies (Tansley and Newell, 2007a, 2007b). We suggest that this means that project team members are consistently engaging in identity work (Ashforth et al, 2000), both as individuals and as a project team, as a way of constructing a positive team identity which can strengthen the building of both social resources (Dutton et al, 2010) and social capital (Newell et al., 2004) for successful project completion.

In order to expand further the theoretical aspect of our research, we critically reflect on the conceptual grounding of personal and social identity

\section{Framing personal and social identity}

Self-identity has been described as referring to subjective meanings and experience by drawing upon feelings, values and behaviour whilst considering 'Who am I?' and 'How might I act?' (Cerulo, 1997). However, because identities are constructed in relationships with others (Gergen, 1994), collective notions, such as social and organizational identities ('Who are we?'; 'How might we act'?) are also essential aspects of identity studies. Although identity is a popular concept for investigating a number of phenomena in a wide variety of organizational settings, such as: seeking competitive advantage (Fiol, 2001); undertaking organizational routines (Brown and Lewis, 2011); diversity and leadership (Eagly and Chin, 2010); role performance (Burke and Reitzes, 1981), organizational politics (Thomas and Davies, 2005) and, increasingly, working in information technology (Nach and Leguene, 2010), there has been little empirical examination of identity work of individuals (Storey et al., 2005; Watson, 2008) and no explicit studies of social identity work at project team level in the context of e-HRM.

Several different ways of philosophically framing the notion of identity have been identified by various authors in organisational analysis. Alvesson et al. (2008, pps 8-9) identify three distinct frames (functionalist, interpretivist and critical) used by scholars which, whilst using different ontological, epistemological and methodological approaches, all include a link between identity and action in some way, albeit taking different stances when identifying what practical steps might be taken in any interventions. Drawing from Habermas (1972), they advise that the 
dominant approach is the functionalist 'technical' frame, which 'aims at developing knowledge of cause-and-effect relations through which control over natural and social conditions can be achieved' and which 'may hold an important key to a variety of managerial outcomes and thus the potential to improve organizational effectiveness' (op.cit, p8).

A second frame is the 'practical-hermeneutic', concomitant with interpretivist scholarship and where the focus is on 'how people craft their identities through interaction, or how they weave 'narratives of self' in concert with others and out of the diverse contextual resources within their reach' and which for 'interpretively inclined organizational researchers', provides 'a vital key to understanding the complex, unfolding and dynamic relationship between self, work and organisation (Alvesson et al. 2008, p8). The third frame, 'emancipatory', involves a critical approach highlighting how power relations which constrain agency might be identified and addressed through relations of control and resistance.

Although we recognise that all three frames have value (Alvesson, 2010), given our interpretive orientation as researchers, we take the second, practical-hermeneutic, frame as a way of examining the lived meaningful experiences of e-HRM project team members in their social and organisational milieu. We also look to critical management scholars for pointers on the dangers of taking a purely managerialist perspective

\section{Framing identity stability: identity as a static entity or as fragmented, in flux and ambiguous?}

Those who take an interpretive, practical-hermeneutic frame to identity studies are particularly sensitive about the way in which concepts used in their studies are ontologically and epistemologically construed, for example, in a consideration about the stability of the identity concept as applied in practice. In the past there has been a tendency for (functionalist) organisational scholars to construe identity as 'a subjective sense of invigorating sameness and continuity' (Erikson, 1974, p17 in Wetherell and Mohanty, 2010, p278). This 'static' notion is also invoked in Albert and Whetton's (1985) seminal work on identity as 'central, distinctive and enduring' (Schultz, Hatch and Larsen, 2000). In their typology of different approaches, Beech and McInnes characterise this static 'ideal type' as a functionalist scholarly frame where 'individuals are singular and consistent, they have attributes that may change over time, but which are consistently located within the person, and boundaries between that person and others are clear and incontrovertible' (2005, p9). This approach has been found, not unnaturally, to be naive and analytically limiting, not least because of the sole focus on the individual.

The notion of social identity has also received much functionalist attention by scholars, who have produced a variety of essentialist definitions of the concept. Ashforth and Mael define social identity as 'the perception of oneness with a group of persons' $(1989$, p. 20). Kogut and Zander (1996) argue that organisations can be categorised by social identity, given that organisational actors connect together in their joint endeavours to support their organisation in survival and expansion. Tajfel and Turner (1979), Haslam (2001) and Oakes, Turner and Haslam (1991), amongst others, suggest that social identity provides for 'ways in which individuals can be seen as part of a collective entity in the mind of themselves and others, by analysing processes of (self-) categorization and psychological commitment' whilst elaborating 'on the likely causes of such ties between the individual and the collective', specifying 'the circumstances under which these ties are likely to increase or decrease in strength' and detailing 'the consequences for social and organizational behaviour' (Haslam et al, 2003, p. 359). The results of social identity, Willem et al. argue, are 'a collective mind and a shared understanding 
among the group members (Haslam et al., 2003), who therefore believe and accept the same values (i.e. the values of the group with which one identifies)' $(2007$, p. 4).

We argue that, at project team level, social identity does not always follow the neat prescription cited by Willem et al. (2007), but rather that it has many paradoxical characteristics. The practices of teams working on IS projects, we suggest, take place in a context where normative identities of both the personal and social kind are shaped by social engagement in organisational processes, and influenced by people's experiences, actions and forms of compliance, consent and resistance as they enact those processes (Webb, 2006). That is, their work is not only influenced by the shaping processes of their personal identity, but also by the shaping processes of their social identity as a project team.

Ybema et al. (2009 connect personal and social identity shaping processes and major on the messiness of identity in human agency, arguing that 'the social processes implicated in identity formation are complex, recursive, reflexive, and constantly 'under construction'(p301). They suggest that the appearance of stability in any given 'identity' is, at best, a transient accomplishment: discursive construction and re-construction emerge as a continuous process and stability appears to be either a momentary achievement or a resilient fiction. Thus, identity shaping is conceptualized as 'a complex, multifaceted process which produces a socially negotiated temporary outcome of the dynamic interplay between internal strivings and external prescriptions, between self-presentation and labelling by others, between achievement and ascription and between regulation and resistance' (Ybema et al. 2009. p301).

One question that these two ways of framing raises for our study is in what way, then, can identity be coherent'? To address this as interpretivists, rather than taking identity as either a static and unshakable entity (Ashforth, 1998; Gioia et al., 2000) or as purely 'characterised by paradox, fluidity, inconsistency and being constantly emergent' (Pullen and Linstead, 2005, p3), we demonstrate coherency by keeping an interest in identity uniformities and configurations, whilst at the same time embracing the views of those who take identity to be impermanent, context-sensitive and emerging set of social constructions, For, as Jenkins suggests, identity is 'not fixed, immutable or primordial', but because 'it is utterly socio-cultural in its origins', it is therefore 'somewhat negotiable and flexible' $(2008, \mathrm{p} 19)$. What this, then, directs us to is the role of human agency in identity shaping processes in organisational life. Sveningsson and Alvesson suggest that a useful way of studying this is by taking the notion of identity work as an analytical tool to enable the "conceptualization of the ways in which human beings are continuously 'engaged in forming, repairing, maintaining, strengthening or revising the constructions that are productive of a sense of coherence and distinctiveness' (2003: 1165).

\section{Identity work}

The human agency involved in the shaping of identity has been described in various ways, including: 'identity construction', 'identity management', 'identity achievement', 'identity manufacture', 'identity project' and 'identity work' (Watson, 2008, p127). The term identity work is used in the fields of social science as a complex and unpredictable endeavour (Cohen and Taylor, 1978; McDermott, 1976; Stewart and Strathern, 2000; Pullen, 2005) and by organisation and management researchers (Alvesson and Willmott, 2002; Storey et al. 2005; Musson and Duberley, 2006; Watson, 2001, 2008). In this paper we take Watson's definition, where 'identity work involves the mutually constitutive processes whereby people strive to shape a relatively coherent and distinctive notion of personal self-identity and struggle to come to 
terms with and, within limits, to influence the various social-identities which pertain to them in the various milieu in which they live their lives $(2008,129)$.

\section{The internal/external dynamics of the personal and social in project team identity work}

As we have seen so far, explanations of identity work are often focused on the development of the 'self' as an 'internal' aspect of identity (Watson, 2008). However, as Watson firstly reminds us, "'the looking glass self" (Cooley, 1902) establishes that "who we take ourselves to be is very much a matter of the person whom we see reflected in the eyes of others', and, secondly, that our 'presentation of self in everyday life' (Goffman, 1958) indicates that "we "manage" the image of that 'person' to influence how those others see us' (Watson, 2008, p127). One of the means by which identity regulation can occur is by 'defining a person by defining others' (Alvesson and Willmott, 2002: p629). In such image management activities, the dialogic nature of our discourse (Bakhtin, 1981) is an important aspect, not least the public and private rhetorical aspects of our everyday arguing and thinking about how to act (Billig, 1987), where 'our very process of thinking and decision-making involves us in a dialogue in our minds with the arguments of human others' (Watson 2001, p23). The interplay between self-identity and social-identity can, then, be seen in the 'link between the 'self" aspects of identity and the discourses to which they relate. This "missing link" is an 'external' or discursive notion of publicly available 'personas' or social-identities' (Watson, 2008, p127).

In this paper we focus particularly on the many forces that pressurise project team social identity of the hybrid kind, specifically those project teams working on implementations for specific functions or divisions, as they attempt to build an understanding of themselves for others that is 'coherent, distinct and positively valued'(Alvesson et al., 2008, p15). We seek to answer two research questions in this study: 'Why should those working in 'hybrid' project teams need a coherent social identity?' and 'What practical difficulties do project team members have in assembling a coherent social identity for themselves and others?' Such a focus is important because in project management practice there has long been an assumption that hybrid experts are the panacea for problems associated with cross-functional IS projects because of the breadth and depth of the multi-dimensional knowledge and skills they bring to their endeavours. Taking a social identity construction lens allows us to critically illuminate such a view.

The structure of the rest of the paper is as follows. We first introduce the conceptual foundations of our study, with a strong emphasis on the theory of social identity in the context of hybrid eHRM projects, examining how social identity work is conceptualised by the current literature. A conceptual framework is then derived from the review and used as a sensitizing device to guide our interpretation of empirical evidence. We do this not only to gain an in-depth understanding about the human experience within organisational projects, but also to reveal issues, and in many instances irrationalities, connected with the relational nature of project team identity work. Next, we explain how we conducted our interpretive case study and analysed the collected data. Then, we illustrate in detail the case study scenarios depicting the dynamic interplay between different dimensions of social identity work and the unintended consequences of project team members' roles in the shaping of what we are calling project team identity ambiguity. This allows us to take account of 'the resources or materials out of which identities are crafted', such as the embodied practices of what people do at work, material and institutional arrangements and groups and social relations (Alvesson et al., 2008, p. 18). Following that, we compare and contrast our findings with the current literature to showcase the theoretical contributions of our study. We conclude by identifying both theoretical and practical implications of hybrid project team's 
identity work and the need to pay attention to the management of a project team's identity ambiguity.

\section{THE HYBRID NATURE OF E-HRM PROJECT TEAMS}

The supply and utilization of e-HRM systems to support the management of people in organisations has grown in the last decade, informed not least by changing demands of those delivering HR services, including individual specialists in HR, line managers, HR self-service centres and those in outsourced HR services (Ulrich, 1996; Cooke et al., 2005). E-HRM has various degrees of application and different levels of sophistication (Stroehmeier, 2007), gained from the increase in operational, relational and transformational utilisation of e-HRM technologies (Thite and Kavanagh, 2009) for both networking and supporting actors in their shared performing of HR activities (Lepak and Snell, 1998). Organisations can be criticized for lack of innovation in HR information management, for e-HRM systems are still being used mainly for day-to-day transactional and record keeping activities for HR tasks (e.g. employee recruitment, selection, reward, development and performance management), with value-added transformational activities limited to the management of employee information across the whole employee life cycle. Recent developments include the shift from transactional HRM to the design of web-based HR self-service systems involving the provision of HR services for relating directly to employees and managers. However, this essentially only equates to a shift in the delivery of transactional HRM from an approach which is 'labor intensive' to one which is a 'technology intensive' utilization of software (Florkowski and Olivas-Lujan, 2006) by a variety of stakeholders.

A number of organisational benefits of e-HRM have been posited (Hawking, Stein and Foster, 2004; Ruta, 2005; Stroehmeier, 2009), including: the facilitation of a more strategic role for the HR function (Snell et al., 2002; Gardner et al., 2003), improvement of HR service efficiency (CIPD, 2005), HRM cost reduction (Buckley et al., 2004) and engendering organisational global orientation (Ruël et al., 2007) to enable the sharing of common HR data across the enterprise in a real-time environment (Bondarouk and Ruël, 2009). However, as 'a way of implementing HR strategies, policies and practices in organizations through a conscious and directed support of and/or with the full use of web-technology-based channels' (Ruël, et al., 2007, p. 281), many technical and organisational challenges exist in e-HRM systems implementation (Marler, 2009), often resulting in delays and budget over-runs (Strohmeier, 2007). Challenges such as the acceptance or rejection of technology and the influence of the dynamic and fluid social interplays which characterize e-HRM implementation (Bondarouk and Ruël, 2009) are wellresearched in the general IS literature (Davis, 1989, 1993; Ahuja and Thatcher, 2005; Kim and Son, 2009). Less researched is how the e-HRM project team (typically composed of both IS specialists and representatives from the 'home' function where the system will be utilised and charged with accomplishing project implementation) deal with managerial and organisational pressures to succeed.

Once recruited, a hybrid project team member may stay for the duration of the project, may revert back to their functional 'home' area or, having gained valuable experience, move on as a wholly-formed hybrid expert to work in another part of the organisation. However, whilst working on the project such a hybrid project team is required to 'creatively explore how the potentially powerful (...) package can be exploited to transform organizational processes (Newell et al., 2004)' (Newell et al, 2008, p. 1-2). This, we argue, requires the project team and its management to focus on their social identity, that is on the questions 'who are we and how should we act?' in light of project deliverables to their clients. However, as we demonstrate in 
our case study, this does not occur in some projects, to serious affect.

In our theorizing we first present what we see as three essential practice dimensions of social identity work at e-HRM project team level: project team management, value propositions and knowledge practice, which has emerged from a critical review of the literatures in IS, knowledge management and e-HRM. We also emphasize their dynamic interrelationships. Second, we incorporate the perspectives of both the project team and their clients into the conceptualization, so that the typology can be used to address the relational aspect of project team social identity work. It is vital to note that, as a relational phenomenon, the two perspectives cannot be examined in isolation. Rather, each perspective individually and collectively influences the social identity work process.

\section{Hybrid project team management and their social identity work}

From a social identity perspective, management of a project team is partly about establishing standards for how team members should define themselves, as well as structuring and regulating the identity of a whole team (see Alvesson and Willmott, 2002) to ensure organisational goals are met. This is especially the case when hybrid characteristics which form the essential backbone of a project team need to be taken into account. On the one hand, a lack of formalization can have benefits, for such creative, flexible processes require e-HRM project teams working as occupational 'hybrids' across disciplines (IS and HRM). For example, because e-HRM projects involve essentially creative processes, this allows for the project team to operate with a fair degree of decision autonomy, whilst at the same time allowing team members 'to respond more flexibly and speedily to external demands, unconstrained by the normal hierarchical and functional boundaries (Gann and Salter, 2000) that 'restrict communication and interaction in bureaucratic organizations' (Newell et al., 2008, p. 2).

On the other hand, there are disadvantages to a lack of formalization, because by its very nature a hybrid project team social identity structure can be problematically multiple, fragmented, processual and situational (see Kärreman and Alvesson, 2001; Brown et al., 2005), not least if their activities are viewed by their clients as ambiguous and lacking role clarity. This can 'add to task uncertainty and requires professionals to partly (re-)create their roles during the course of a client assignment' (Morris and Empson, 1998, cited in Alvesson, 2001, p. 876).

\section{Hybrid project team value propositions and their social identity work}

The next stage for such a project team should be joint efforts with their clients to clearly establish and agree project purposes, promises and resource availability (Elias et al., 2002; Larson and Wikstrom, 2007), and, in the case of e-HRM, that these are then understood by their HR functional clients in order for transformational HR services to take place. Project team leaders must sequence, time and articulate core messages about their projects to the right audiences. We argue that this requires that they give thought to the value propositions (or promises) their project teams offer and demonstrate how this service/product is positioned compared to other services within the organisation. We constructed a definition of value propositions for our study:

Value propositions of a project team comprise the promises and commitment the team makes to their internal clients to deliver a package of relevant services and products which uniquely meets internal clients' needs. The strength of the value propositions 
depends upon the consistency and clarity of how well these promises are communicated to clients and how well the team fulfils its promises.

This working definition is drawn from the principles of traditional brand management from the field of marketing (Ettenson and Knowles, 2008, p. 18) and applied to e-HRM project team planning, development, launch and delivery of project initiatives. From this perspective, a unique value proposition expressed in a relevant and differentiated way can create preference and loyalty among key audiences. However, as we have theorised, project team identities can be multiple, which can impact on the creation of appropriate promises for client services, and, we argue, this can be particularly true when hybrid teams are formed.

\section{Hybrid project team knowledge practice and their social identity work}

Social identity is a developmental process in which individuals classify themselves and others in groups and perceive oneness with a group, resulting in certain behaviour and outcomes (Ashforth and Mael, 1989; van Knippenberg, van Knippenberg, Monden, and de Lima, 2002; Willem et al., 2007). Because project teams are involved in constant improvisation of social interactions within organisations, the distinctiveness of a project team's social identity from a knowledge perspective therefore lies in their members being able to characterize their knowledge in three ways: what they claim their core product/service knowledge to be; how they are applying that knowledge and what the results and application of their knowledge is taken to be in their work. However, Alvesson suggests that 'difficulties in demonstrating competence and performance and the significance of producing the right impression make work identity difficult to secure' (2001, p. 864).

To address these difficulties, we suggest one helpful analytical perspective is to characterize project team endeavours as knowledge practice, given that they involve the skilful application of cognitive rationality based on superior knowledge of the system and its application in organisational work (although see Alvesson's critique of this definition in 2001, p. 864). The processes of social identity work can become complex when taking into account the organisational context where knowledge practice is put into action. For instance, Ivory et al. (2007) show that in complex multi-organisational and fragmented contexts where sharing knowledge across organisational and inter-organisational boundaries is essential, the motivation of different groups to do so can be unevenly distributed across the structure and temporal span of the project and the incentives to engage in knowledge generation and sharing wax and wane over the life of a project.

In Table 1, below, we examine in greater detail these three interrelated dimensions of project team social identity work in three categories: 'basis for project team construction', 'core assertions about project team identity', 'illustrative studies or approaches' and draw these together as 'core propositions': 
TABLE 1: Three interrelated dimensions of a hybrid project team's social identity work

\begin{tabular}{|c|c|c|c|}
\hline & $\begin{array}{l}\text { Project team } \\
\text { management }\end{array}$ & Value propositions & Knowledge practice \\
\hline $\begin{array}{l}\text { Working } \\
\text { definitions of } \\
\text { dimensions of } \\
\text { project team } \\
\text { social identity } \\
\text { work }\end{array}$ & $\begin{array}{l}\text { Management of a } \\
\text { hybrid project team is } \\
\text { partly about } \\
\text { establishing standards } \\
\text { for how team members } \\
\text { should define } \\
\text { themselves, then } \\
\text { regulating the social } \\
\text { identity of the whole } \\
\text { team. }\end{array}$ & $\begin{array}{l}\text { Value propositions of a project } \\
\text { team comprise the promises and } \\
\text { commitment the team makes to } \\
\text { their internal clients to deliver a } \\
\text { package of relevant services and } \\
\text { products which uniquely meets } \\
\text { those clients' needs. The strength of } \\
\text { the value propositions depends } \\
\text { upon on the consistency and clarity } \\
\text { of how well these promises } \\
\text { are communicated to clients and } \\
\text { how well the team fulfils its } \\
\text { promises. }\end{array}$ & $\begin{array}{l}\text { We take project team knowledge } \\
\text { practice as the skilful application } \\
\text { of cognitive rationality based on } \\
\text { superior knowledge of the e- } \\
\text { HRM system and HR functional } \\
\text { work, as well as its application in } \\
\text { organisational activities. By } \\
\text { putting knowledge into action } \\
\text { and/or through interaction, a } \\
\text { project team as a whole and its } \\
\text { individual members are also } \\
\text { engaging in the process of } \\
\text { identity work. }\end{array}$ \\
\hline $\begin{array}{l}\text { Core } \\
\text { assertions } \\
\text { about project } \\
\text { team social } \\
\text { identity work }\end{array}$ & $\begin{array}{l}\text { When project } \\
\text { intricacies impact upon } \\
\text { team effectiveness or } \\
\text { prevent managerial } \\
\text { control of performance, } \\
\text { clarification of project } \\
\text { team identity is one } \\
\text { way of defending } \\
\text { requisite priorities and } \\
\text { exertions. }\end{array}$ & $\begin{array}{l}\text { We assert that value propositions } \\
\text { are the mix of characteristics, } \\
\text { benefits, and ways of working of a } \\
\text { project team in an organisation. } \\
\text { Value propositions are an important } \\
\text { part of the 'deal' struck between a } \\
\text { team and its clients with regard to } \\
\text { team contribution and performance. } \\
\text { This 'deal' characterizes the team } \\
\text { social identity as it represents the } \\
\text { promises it is making for service } \\
\text { and differentiates it from its } \\
\text { competition, if there is any } \\
\text { competition. }\end{array}$ & $\begin{array}{l}\text { We assert that attempts by project } \\
\text { teams to find answers to social } \\
\text { identity questions such as 'who } \\
\text { are we?' and 'how should we } \\
\text { act?' are majorly informed by } \\
\text { institutionalized assumptions and } \\
\text { expectations about the possession } \\
\text { and application of the team's IS, } \\
\text { HR and e-HRM knowledge. } \\
\text { However, in parallel with this } \\
\text { endeavour, individual team } \\
\text { members need to engage in social } \\
\text { identity work by exhibiting high } \\
\text { levels of knowledge, skills and } \\
\text { competences in their practice. } \\
\text { Successful achievement of this } \\
\text { endeavour can lead to positive } \\
\text { team image and reputation. }\end{array}$ \\
\hline $\begin{array}{l}\text { Illustrative } \\
\text { studies or } \\
\text { approaches }\end{array}$ & $\begin{array}{l}\text { Söderlund (2011); } \\
\text { Newell et al., } \\
\text { (2004); Eppler and } \\
\text { Sukowski (2000); } \\
\text { Fournier (1999). }\end{array}$ & $\begin{array}{l}\text { Elias et al. (2002); Ettison and } \\
\text { Knowles (2008); Larson and } \\
\text { Wikstrom (2007); Lederer and } \\
\text { Gardiner (1992). }\end{array}$ & $\begin{array}{l}\text { Alvesson (2001); Alvesson and } \\
\text { Willmott, (2002); Newell } \text { et al., } \\
(2002) \text {. }\end{array}$ \\
\hline
\end{tabular}

From the three dimensions of a hybrid project team's social identity work shown above, we construct a number of propositions. Firstly, hybrid project team management involves taking into account that there is pluralism in project team social identity which is derived from a multiple range of expertise and diverse variations of specialization. Project team formation is therefore based on strategic but ever changing requirements of the organisation, which can mean that the project team is perceived as a panacea. Secondly, that hybrid project team value propositions may be identified in specific acts, behaviours, policies and practices and visible symbols for interaction with stakeholders' inside and outside the organisation. These form an important part of the project team's identity work, both during project duration and afterwards. Thirdly, the distinctiveness of a hybrid project team's identity lies in their members being able to characterize: (i) their claimed core product/service knowledge; (ii) how they are applying that knowledge and (iii) the results.

In this paper, in order to bring the categories above into our social identity analysis of the case study of the e-HRM project team of an enterprise-wide ERP system of a global organisation and apply our three associated dimensions of project team identity work (project team management, 
team 'value propositions' and the team's 'knowledge practice') to examine and conceptualize an e-HRM project team with its distinct hybrid characteristics, we identify two further elements. These relate to the perceived generalized norms of the project team and those of their clients. By this we mean the prominent project team client-serving activities deemed to be of most importance by each party engaged in the project. Our rationale for this choice is that by emphasizing the relational dynamics that are commonly observed in functional project teams (Newell et al., 2004), we are able to actualize the notion that project team social identity is not merely something that the team intends to socially construct for, and present to, its stakeholders, but also something that its stakeholders form through their social interaction with the team. Specific features of both parties' generalised norms in relation to the three identified areas of importance are shown in table 2 , below. 
Table 2: Expected norms of E-HRM project client-serving activities

\begin{tabular}{|c|c|c|c|}
\hline & Project team management & Value propositions & Knowledge practice \\
\hline $\begin{array}{l}\text { Clients' } \\
\text { expected } \\
\text { norms of } \\
\text { the project } \\
\text { team } \\
\text { [Davis, 1993; } \\
\text { Elias et al., } \\
\text { 2002; Fiol, } \\
\text { 2001; Gann } \\
\text { and Salter, } \\
\text { 2000; Gardner } \\
\text { et al., 2003; } \\
\text { Hawking et } \\
\text { al., 2004; } \\
\text { Ivory et al., } \\
\text { 2007; Kim } \\
\text { and Son, } \\
\text { 2009] }\end{array}$ & $\begin{array}{l}\text { A effective project team } \\
\text { should: } \\
\text { - } \\
\text { have a clear understanding } \\
\text { of the requirements of their } \\
\text { clients. } \\
\text { give full commitment to the } \\
\text { project sponsor or owner } \\
\text { (e.g. HR or IS) regardless } \\
\text { of how many stakeholder } \\
\text { groups are involved. } \\
\text { self-manage its diversity of } \\
\text { expertise and the } \\
\text { complexity of project scope } \\
\text { in order to deliver the } \\
\text { client's requirements. } \\
\text { respond to changing } \\
\text { organisational structures } \\
\text { generating associated } \\
\text { changes in the requirements } \\
\text { for a team's skills and } \\
\text { knowledge. } \\
\text { respond to clients concerns } \\
\text { about how to define the } \\
\text { progress of the projects } \\
\text { enable clients to evaluate } \\
\text { their performance through } \\
\text { formal control mechanisms. }\end{array}$ & $\begin{array}{l}\text { The project team value } \\
\text { propositions (promises) } \\
\text { should be meaningful to } \\
\text { the full range of clients to } \\
\text { enhance the overall } \\
\text { performance of the } \\
\text { organisation. } \\
\text { - Clients require a direct } \\
\text { match between team value } \\
\text { propositions and their } \\
\text { expectations. } \\
\text { The client expects the } \\
\text { value propositions to } \\
\text { constantly evolve as the } \\
\text { expectations at both } \\
\text { organisational and client } \\
\text { level constantly change. } \\
\text { The value propositions } \\
\text { promised by the team } \\
\text { should enable the client } \\
\text { deliver the value } \\
\text { propositions which the } \\
\text { client has promised the } \\
\text { organisation. }\end{array}$ & $\begin{array}{l}\text { An effective project team } \\
\text { should: } \\
\text { - deliver the } \\
\text { specifications that } \\
\text { are perceived by the } \\
\text { client to be the } \\
\text { essential strategic } \\
\text { goals of the } \\
\text { organisation. } \\
\text { have both superior } \\
\text { technical systems } \\
\text { knowledge and the } \\
\text { know-how to apply it } \\
\text { to HR practice. } \\
\text { HR capability is } \\
\text { maximized through } \\
\text { integrated and interactive } \\
\text { technologies } \\
\text { Given that a hybrid is not } \\
\text { a specialist, they should } \\
\text { be flexible in taking on } \\
\text { under-defined tasks. }\end{array}$ \\
\hline $\begin{array}{l}\text { Project } \\
\text { team } \\
\text { expected } \\
\text { norms of } \\
\text { themselves } \\
\text { [Bondarouk } \\
\text { and Ruël, } \\
\text { 2009; Brown } \\
\text { and Lewis, } \\
\text { 2011; Dutton, } \\
\text { et al., 2010; } \\
\text { Epper and } \\
\text { Sukowski, } \\
\text { 2000; } \\
\text { Florkowski } \\
\text { and Olivas- } \\
\text { Lujan, 2006; } \\
\text { Newell, et al., } \\
\text { 2002] }\end{array}$ & $\begin{array}{l}\text { An effective project team } \\
\text { should: } \\
\text { - } \quad \text { be aware of IS and well as } \\
\text { HR project protocols, } \\
\text { standards of work required } \\
\text { and be fully committed to } \\
\text { the multiple functionalities } \\
\text { that they represent. } \\
\text { - Have a good understanding } \\
\text { of multiple clients' needs } \\
\text { and be able to prioritise } \\
\text { about their different needs. } \\
\text { adhere to organisational } \\
\text { policies, which might not } \\
\text { necessarily be in the best } \\
\text { interests of the client. }\end{array}$ & $\begin{array}{l}\text { - Maximizing cross- } \\
\text { functional (hybrid) project } \\
\text { work enables enactment } \\
\text { of an organisation's } \\
\text { strategic intent. } \\
\text { The project team value } \\
\text { propositions are drawn } \\
\text { from IS protocols and } \\
\text { linked to HR functional } \\
\text { requirements. } \\
\text { Because clients have a } \\
\text { tendency to see the value } \\
\text { propositions from their } \\
\text { own functional } \\
\text { perspectives, a mismatch } \\
\text { between what the team } \\
\text { offer and what is expected } \\
\text { by its clients inevitably } \\
\text { generates discord which } \\
\text { needs to be managed. }\end{array}$ & $\begin{array}{l}\text { An effective project team } \\
\text { should have: } \\
\text { - an appropriate, well- } \\
\text { blended set of } \\
\text { knowledge, } \\
\text { experience and skills } \\
\text { to enable the delivery } \\
\text { of the project goals. } \\
\text { An expectation that } \\
\text { their clients trust } \\
\text { their expertise in } \\
\text { meeting project } \\
\text { deliverables. } \\
\text { A team's knowledge base } \\
\text { can evolve around } \\
\text { individual availability } \\
\text { rather than fulfilling } \\
\text { client requirements. } \\
\text { Due to undertaking a } \\
\text { myriad of roles, hybrid } \\
\text { team members } \\
\text { understand the dangers of } \\
\text { becoming 'jack-of-all- } \\
\text { trades and master of } \\
\text { none'. }\end{array}$ \\
\hline
\end{tabular}


In exploring the interrelationship between the three dimensions and two perspectives we chose a global organisation's e-HRM implementation as a case study.

\section{RESEARCH CONTEXT AND METHODS}

This study is part of an ongoing research program aiming at developing practice-oriented theories arising from human relations aspects of the design, development, implementation and running of HR information systems within large multi-national organisations. This particular study focuses on an e-HRM project team working on the HR 'pillar' of an enterprise-wide project in a multi-national engineering company with a strong emphasis on issues about relational and communication problems with e-HRM client groups.

\section{Case context: e-HRM implementation in Flow plc}

Flow plc ('Flow') is an international engineering company headquartered in the UK employing 40,000 employees. In 2002 an enterprise resource planning (ERP) system was introduced to reduce wasteful repetition of over 1600 different legacy systems by aligning data management across functions. SAP solutions were employed to optimize the performance of the business by gaining insights for improved business performance, efficiency for optimized operations and flexibility in their management systems to adapt to changing circumstances. Their aims were to: ensure greater transparency of, and accountability for, business information, as well as to become leaner and more agile, customer-centric and collaborative to increase profitability through case management, risk mitigation, customer loyalty, streamlining operations, engendering sustainability and addressing global talent management. The HR components of the system included: personnel administration; organisation management; reward; time management; payroll; resourcing; travel and expenses; training and events management; global mobility; occupational health and reporting and personal development. Figure 1, below, shows how the e-HRM team was positioned within company IS project structures:

\section{FIGURE 1: E-HRM teams within the Flow organisational context}

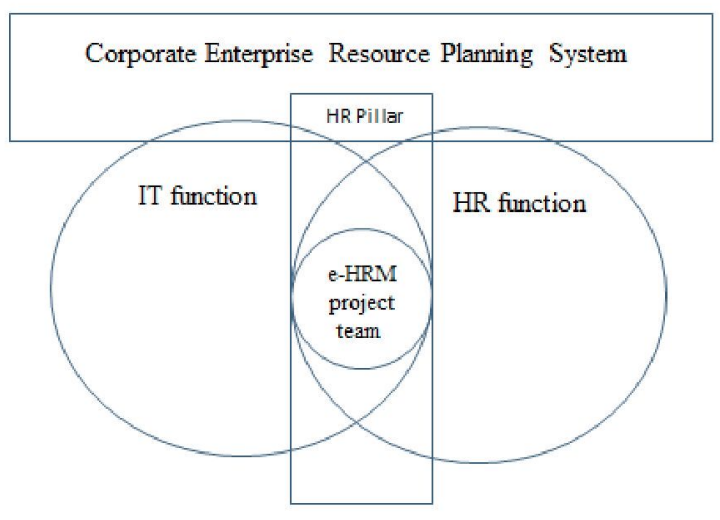

In responding to client needs, Flow's corporate e-HRM development team had grown organically over the last 10 years to eight members in the UK central e-HRM team and six in eHRM teams in other geographies. This growth had been driven both as a result of embracing the addition of different parts of the business operating in different countries (USA, Canada and Germany) and the associated expansion of SAP HR technology and functionality in the UK. We 
will present more empirical insights in the later case study section.

\section{Research methods}

We have adopted a case study research design with a strong interpretative orientation as this is particularly suitable for inquiries on research phenomena that are dynamic in their creation and fluid in their sense-making (Walsham, 1995), as found in this research on project team social identity work and the emergence of identity ambiguity from team member-stakeholder interactions. Following the tradition of interpretive case study research, the role played by existing theories is not merely in shaping, framing and guiding the research direction and process, but also in providing a foundation where new findings and their interpretations can be built on (Klein and Myers, 1999). Core to the spirit of interpretive case study research is the development of a conceptual framework through which researchers demonstrate a synergetic yet innovative understanding of the relevant literature, and use it as a tool to engage and connect the research phenomena with the existing theoretical landscape (Pan and Tan, 2011).

As elaborated in the earlier section, our goal was to build on and enrich the existing conceptualization of social identity work and hybrid job design by exploring those two concepts in the context of the e-HRM project team. With such intent in mind, developing a conceptual framework from the review of existing literature review has led us to yield Table 2 which is a conceptual progression from Table 1 . As outlined in Table 2 , the three distinctive yet interrelated constituents of project team social identity work were mapped against the two perspectives that form the relational basis of the project context. The set of conceptual themes listed in Table 2 served as 'sensitizing devices' (Klein and Myers, 1999) to adjust our analytical focus, guide our data collection and facilitate the analysis and interpretation of the collected data. As recommended by Bryman and Bell (2003), efforts to evaluate qualitative interpretive research should be incorporated into the research design and guiding data collection and analysis, rather than something that is applied once the research is completed. Details related to the processes of data collection and analysis, as well as how their qualities were evaluated and ensured, are outlined below.

A research protocol was used to ensure consistency across the data collection process (Lincoln and Guba, 1985; Lincoln and Denzin, 1994; Bryman and Bell, 2003). The data collection process for this study took place over the course of over one year between April 2007 and May 2008. Four main sources of empirical evidence were collected through interviewing, on-site observation, documentation and informal dialogues with the researched for triangulation purpose (Lincoln and Denzin, 1994), as well as to enrich the findings (Klein and Myers, 1999).

In total, twenty five interviews were conducted in Flow, with e-HRM stakeholders from their HR and IS functions in the UK, Germany, Canada and the USA, each lasting up to two hours and digitally tape-recorded. The list of interviewees is outlined in Table 3 . To ensure that we fully explored the relational nature of identity work, we have selected the respondents to represent both sides of the relationship. All interviews were undertaken using an interviewing convention with a chronological underlying form. Each respondent was asked to use real-life examples and describe such experiences in detail. Probing questions were asked. Electronic and hand-written records were also made throughout the research process, including extensive notes of informal discussions and telephone calls with various members of the e-HRM team. 
TABLE 3: The list of interviewees

\begin{tabular}{|c|c|c|}
\hline $\begin{array}{l}\text { e-HRM } \\
\text { stakeholder }\end{array}$ & Explanation of role and context & No. \\
\hline $\begin{array}{l}\text { e-HRM project } \\
\text { leaders }\end{array}$ & $\begin{array}{l}\text { Individuals responsible for e-HRM project teams in a particular } \\
\text { geography (e.g. UK corporate HQ; USA; Canada and } \\
\text { Germany) }\end{array}$ & 4 \\
\hline $\begin{array}{l}\text { Corporate HQ e- } \\
\text { HRM project team }\end{array}$ & $\begin{array}{l}\text { Comprising: e-HRM business analysts, HR specialists such as } \\
\text { payroll and technical maintainers 'permanently' on the project }\end{array}$ & 6 \\
\hline $\begin{array}{l}\text { Project teams } \\
\text { outside UK }\end{array}$ & $\begin{array}{l}\text { Comprising: e-HRM specialists such as payroll and technical } \\
\text { maintainers }\end{array}$ & 6 \\
\hline \multirow[t]{2}{*}{ Clients } & $\begin{array}{l}\text { Business HR managers/directors: HR generalists with major } \\
\text { responsibility for HR services within individual businesses in a } \\
\text { particular geography/high level users of e-HRM systems in } \\
\text { 'day job' }\end{array}$ & 2 \\
\hline & $\begin{array}{l}\text { HR managers with special responsibilities who are located in } \\
\text { the corporate headquarters and are major 'clients' of the } \\
\text { corporate e-HRM team. } \\
\text { Responsibilities of these managers include the management and } \\
\text { future development of expert centres in the HR function, such } \\
\text { as shared service centres. High requirement for e-HRM } \\
\text { systems. }\end{array}$ & 4 \\
\hline $\begin{array}{l}\text { Other internal } \\
\text { specialists }\end{array}$ & $\begin{array}{l}\text { HR specialists with a particular role across businesses (e.g. } \\
\text { quality assurance) but with a specific, temporary task on the e- } \\
\text { HRM project or interviewed as corporate experts (e.g. branding } \\
\text { or payroll systems) }\end{array}$ & 3 \\
\hline \multicolumn{2}{|r|}{ Total } & 25 \\
\hline
\end{tabular}

As well as interview material, we also collected unobtrusive data (Webb and Weick, 1979) from documents relating to the project. These documents included paper and electronic representations of not only the strategic, operational, financial, and cultural aspects of the project but also identity artifacts relating to the social identity of the project team (Corley and Gioia, 2004). This documentation (e.g. project documentation including Powerpoint presentations on content and progress and job descriptions on roles and responsibilities) provide a secondary data source about the project team's identity, project value propositions and knowledge practices and their client's expectations of them. They also proved helpful as a tool (Forster, 1994) for engaging informants in discussions of how specific identity claims and images related to the process of identity work.

To ensure dependability of our data collection (Bryman and Bell, 2003), the use of a research protocol was found to be extremely valuable and crucial. Its value was reflected not only in how all researchers followed a set of predefined procedures to collect data, but also in how the logistics of data collection, in particular the volume of data from interview transcripts, documentations and field notes, can be effectively managed for peer auditing during the data analysis phase. Furthermore, as suggested by Bryman and Bell (2003), credibility is concerned with the feasibility of the account and the extent to which the researchers have consulted the respondents to check that they have understood their accounts correctly (respondent validation). 
Informal meetings were also held to ask team members for feedback on observations the researchers had made about the project team and its stakeholders. These activities ensured researchers were aware of any internal politics which may have influenced objectivity in the study.

\section{Data analysis}

Our data analysis consisted of four interrelated steps, including summarizing, clustering, displaying and comparing the data by applying the theoretical framework outlined in Table 2 . Key points embedded in each interview transcript, document and field note were summarized by each researcher individually. These steps were first carried out during February and March of 2010. Following the inputs from the review process, we have carried out these steps once more to fine-tune our data analysis. In particular, by refining the conceptual substance of Table 2, we are able to strengthen the explanatory power of our theoretical framework

Through comparing the points being summarized, the team was able to crystallize different viewpoints and assumptions that each researcher had towards the data and to encourage intensive and ongoing discussion, so that collective understanding could be established. Once the consensus was achieved, the list of summarized points was used as a basis for clustering and displaying the data into key themes outlined in Table 2 . Through clustering and displaying the data based on Table 2, we were able to examine and interpret each cluster of data on its own right, and at the same time explore their interrelationships. Results derived from our analysis are summarized in Table 4 which will be extensively elaborated later, and depicts our conceptualization of how project team identity work which takes place through the social interaction of the e-HRM project team with its stakeholders. What emerges from the synthesis of key findings outlined in Table 4 is the notion of identity ambiguity, a much more precise concept to label the research phenomenon than what we have originally proposed. The need to ensure the appropriateness and precision in labelling the core research phenomenon is echoed in Denzin's (1997) argument that the researcher always has to be vigilant that $s /$ he is not sacrificing 'truth' for dramatic effect.

\section{CASE STUDY}

In Flow the HR clients had three main e-HRM strategic objectives which they fully expected the e-HRM project team to support them in delivering. The first objective was to ensure effective people management through clear visibility of the talent pipeline, identifying staff leadership potential and to encourage staff engagement. The second was to enable user productivity of the 40,000 members of their workforce through 'best of breed' interactive technologies. Finally, to develop the strategic value of the HR function by ensuring their new HR shared service capability provided value in a shorter timeframe by streamlining HR processes, enabling quick answers to often difficult questions by business managers and supporting staff through an effective use of technologies.

\section{Expected norms and project management}

The Flow e-HRM team were tasked with accomplishing the implementation and operationalization of the SAP HR 'pillar' of the enterprise resource planning system and the expected norms related to the management of both the technical and organisational challenges, as well creatively exploring how the potentially powerful SAP software might be exploited to transform HRM processes. The team was composed of hybrid specialists with multiple identities as a result of varying combinations of HR and IS knowledge, skills and experience. Their clients 
recognized that they worked across the two domains of HR and IS. However, the clients were less interested in IS requirements and majored on HR requirements of the system as these most closely followed their objectives. One client, the head of the HR self service centre, suggested that the e-HRM project team were taking advantage of their hybrid character to both control and escape essential work: "I think the person who's responsible for IS in the [e-HRM] organisation generically flicks in and out of the responsibility levels. On the one hand, they put the noose around the neck of the [HR] function so tightly that you can't do anything. On the other hand, when you do try and do something, they abdicate the responsibility completely and say 'it's got nothing to do with us."

This perception of violation of the norms they expected from the project team led to a growing feeling of discontent from HR clients: "The change and the sudden surprises that sprang out from [the e-HRM] team and from the IS team... it came to the point where you just expect something to be completely wrong. You know, somebody to just lob a grenade in at the last minute and say 'oh yeah, but we haven't got boxes and it will take us six weeks to get those'. 'But we're supposed to be deploying our application next week?' 'Yeah, but we don't order them'. That kind of stuff I just think is unforgivable really. " Furthermore, because e-HRM roles were so fragmented, many HR clients often did not know who to go to for resolution of a particular issue, as highlighted by the Director of the HR Self Service Centre, "So very discoordinated, very uncoordinated. The accountabilities are unclear in terms of project delivery"

In the meantime, individual project team members, whilst understanding the need to have mutual connectivity with their HR clients, saw their project management norms as providing speedy solutions to IS implementation problems which would lead to HR policy implementation. This had led to them expecting, and being increasingly allowed, relative professional autonomy together with a high degree of decision discretion. This resulted in them feeling generally unconstrained by the normal hierarchical and functional boundaries that can restrict communication and interaction in large, transnational organisations. However, in their connectivity with each other, project team members were experiencing negative outcomes of working in a hybridized context. At project team level Flow team members and external consultants interviewed in the UK, Germany, USA and Canada expressed their concerns about lack of clarity of both team identity and their own e-HRM team membership, roles and responsibilities. There was a myriad of project participants: "... we also have... the [Flow] support activity and [the outsourced IS provider] and ... [an additional IS consultancy] ... then [the outsourced IS provider] would contract in additional labour out of [a vendor] or somebody." This ambiguous and confusing situation had arisen from incoherent project roles and responsibilities and was leading to confusion in reporting lines with team members across all countries:

"Are we part of the Flow e-HRM team here? I'm not sure." [Vendor team member, Canada]

"So I sit next to somebody else doing the same job and we're working for two different parts of the organisation. "[Flow UK team member]

"X doesn't see it as his role, and I don't see it as his role but I don't see it as mine either!" [Flow UK team member].

E-HRM team members knew that in some quarters confusion about their team identity meant that their work was not valued, "Nobody likes HR systems. Nobody. I mean, they're an admin thing... I don't think a lot of people are interested in HR, especially the managers. It's very 
difficult." One expressed a feeling that such identity fragmentation didn't help this lack of value, "all we re doing is ... looking at things going wrong and trying to work out why they are going wrong ... So we've got no real interest ... in all how this is working or whether we can influence it. It's there and we've got to put it in"'. Another colleague agreed, "I get the business requirements... I document it and then throw it over the wall to [the vendors] who do the interesting part".

In the UK, the HR director recognized this situation "we sort of muddle by with the resource that we've got ... you know, a beg, borrow and steal sort of approach really, rather than you know, a more controlled [way of resourcing the project teams]'. Such discontent resulted in HR clients beginning to take greater control of their own systems, for example in the HR shared service centre: "We have a better degree of maintenance capability provided by the shared service centre for its own needs now". Part of the reason for this was their unhappiness about quality of service provision by e-HRM which was caused by constant confusion about their social identity.

\section{Expected norms and value propositions}

HR clients expected a full service from the e-HRM team in delivering HRM objectives in value proposition terms and their expected norms included: "guide us 24/7; make our job easy; earn our trust; train us to manage IS ourselves; stay with us; exceed our quality expectations, keep us up to date with the most recent software for the system" [HR client]. They felt this drive towards supporting their independence in operating their own HR systems was a feasible deliverable for the e-HRM team. After all, e-HRM were part of the HR function, weren't they?

In practice, however, the e-HRM team were not full members of the HR fraternity but had reporting lines to senior managers in the IS function and had stringent IS deliverables to the enterprise resource planning (ERP) programme. As their team leader said, "our task is ... to support the business in the US, Canada, the UK and Germany...in the use of technology... in this [HR] process improvement activity..." This IS bias of e-HRM value propositions was not unsurprising given the reach of the systems and the pressure the team were under to deliver SAP enterprise-wide IS solutions. For example, just in payroll, "Given SAP is our enterprise resource planning application, heavily integrated across the business and across the different processes, we now have something like 35,000 people probably paid out of SAP in four countries.."

Constructing and enacting team expected norms was also affected by individual project team members' personal identity confusion. As one UK team member told us, "my daughter, will say to me 'well what do you do? ... what's your job title?' And as I say, I don't really know what my job title is. I don't know what I'd call myself." Furthermore, although team members knew that they needed to get a grip on their personal offering for their future careers, they also knew that clarifying exactly what their offering was to a current or future employer was no easy undertaking because the roles they did were so ambiguous and could change daily. "This worries me because you need to be able to ... say 'this is what I am' because identity in an organisation is linked to what you are offering through your role to the client group as well as the talents and skills that you've got because that's the currency in the labour market now. In my case, am I HR or IS or what? It's confusing".

\section{Expected norms and knowledge practice}


Client norms for knowledge practice by the project team assumed both superior technical systems knowledge and the know-how to apply it to HR practice globally. However, the situation globally was complex with regard to e-HRM hybrids' knowledge practice. For example, the recent conversion to SAP not only meant multiple changes to knowledge and skills requirements of team members across the geographies but there was also no cohesive way that HR and IS knowledge and skills sets were drawn upon across countries. In the USA, each HR function had previously had the PeopleSoft package with separate payroll and their own IS specialists with e-HRM support knowledge. SAP implementation meant amalgamation of HR information and payroll systems which required structural and role changes to take place, not least the creation of a new role for a USA e-HRM project manager. He had knowledge and skills in finance, business support and IS administration and his remit was to address how IS could improve service delivery through HR process improvements informed by IS knowledge. Thus integrated identity boundaries and roles were created from an IS rather than HR perspective, which decreased the magnitude of change but increased blurring, rendering HR boundary creation and maintenance more difficult (see Ashforth et al., 2000, p. 272).

In the UK, in spite of their team leader's focus on IS tasks, e-HRM project team members' knowledge bias lay in HR specialisms, such as payroll. Furthermore, the most expert person in payroll was constantly being called upon to support the HR functional client with payroll policy guidance and this blurred his team role identity as a technology specialist. This meant that in their knowledge practice some team members were in danger of becoming 'jack-of-all-trades and master of none' which further resulted in a lack of clarity about project team and individual identity for HR clients

In the UK in some quarters there was a resignation about having e-HRM specialists sitting in HR. As one HR client manager said, "in a way I don't think we are supposed to have our own [HR] IS people in the organisation, but it's got to be done”. In the UK the HR director was extremely concerned that this was causing blurred identity boundaries, this time between functional HR generalists in business-facing roles and those working in e-HRM roles in the corporate HQ. He was uncomfortable with HR having their own hybrids with IS knowledge and skills, "in HR, you've got this uneasy organisation; it's unclear as to where the [HR] centre... ends and if you like, the HR functional IS department [e-HRM] starts; they merge into each other." His preferred option was to have IS functional specialists working on e-HRM projects. His view was e-HRM people should be replaced with IS business analysts, "within the HR function itself, I think logically you need a handful of analysts who can specify the requirement. ... So there's a ... an IS professional basically, who is skilled and qualified and had the competencies in that sort of arena". [and an HR business analyst] to start with a blank sheet of paper and say right, '... what do we need as a business, what's the requirement? And how can we turn that requirement into a solution?".

It was claimed that there was little understanding of the knowledge and capability of the e-HRM project team. "You know, we 've got the best PowerPoint presentations on talent management I should think anywhere in the world, but is it imbued, is it in the sort of consciousness? No it isn't... it's just not recognising the capability of [e-HRM] people" [project team leader] However, it was recognised by HR clients that team knowledge overall was valuable and concern was expressed about drawing upon that specialist knowledge. "If I'm honest... We put an enormous amount of pressure on these people, because it is such an expensive and complicated project, and we rely on one or two individuals to help see it through and they get exhausted, so we lose knowledge when they leave the project." We asked what would happen if one or two people did drop out of the team for even a short while. One HR client told us: "We' $d$ 
be dead. We would not know where things are... So it is very reliant on certain individuals. I think that's an enormous difficulty."

\section{DISCUSSION}

This study highlights the importance of, and need for, systematic and joint efforts between a project team and their clients not just to clearly articulate the project's key milestones, but also to agree on project purposes, promises and resource availability (Elias et al., 2002; Larson and Wikstrom, 2007). In particular, when a hybrid project team is formed, it has to be accountable to multiple functional stakeholders with different politics and interests to consider, therefore equal attention needs to be paid to the way in which a project team's identity is projected and managed.

In this paper we have taken project team identity as the collective, shared, social sense of who the members are as a team. In this section we synthesize the conceptual grounding outlined in Tables 1 and 2 with the subsequent empirical insights in order to provide an interpretive account of how project team identity is theoretically applied to make sense of the research phenomena social identity work in our inquiry. We have seen in the case study how identity discrepancies occurred in the ways in which e-HRM project team members saw themselves and how they were seen by their clients. This, we are arguing, resulted in a collective state of what we are calling identity ambiguity.

\section{Identity ambiguity}

With identity ambiguity we see multiple possible interpretations of the questions 'who are we and how should we act?', with the term ambiguity denoting 'an on-going stream that supports several different interpretations at the same time' (Weick, 1995, p. 91). Where identity ambiguity exists it creates apprehension for both clients and project teams attempting to make sense of what are, and what could be, the core features of client services in e-HRM projects. Thus, 'ambiguity about identity is uncomfortable, at both the individual and organisational levels and most would like to resolve it quickly to achieve some renewed semblance of clarity about their identity' (Corley and Gioia, 2004, p. 173). As we saw in the case study, however, experiences of identity ambiguity, although unidentified or under-appreciated, resulted in major disruption of the precarious social order and this affected the on-going health of the relationship between the project team and its clients. In such a situation discontent grows and the negative impacts emerging from such identity ambiguity will inevitably mean that answering the question 'Who are we?' is the salient social identity work requirement for future pivotal action to improve relationships with clients.

\section{Relational dynamics across dimensions of hybrid project team identity}

In this section we combine the different elements of identity ambiguity highlighted in this study by bringing together and building on the conceptual essence of Tables 1 and 2 . In Table 1, the three distinctive yet interrelated dimensions of project team identity, including 'project team management', 'value propositions' and 'knowledge practice', were incorporated to capture the multi-faceted characteristics of that notion. In Table 2, the two perspectives, namely clients' expected norms of the project team and the project team's expected norms of themselves, were drawn upon to examine the relational nature of the project setting. More details related to each of the three dimensions, their interplays with the two perspectives and impacts on the notion of identity ambiguity are outlined with our main findings outlined in Table 4 below. This allows us not only to examine each of the issues in its own right, but also enables us to identify and 
establish the notion of 'identity ambiguity' which encapsulates the relational processes and dynamics of project team social identity that we found in our study.

Table 4: Identity ambiguity - a summary of key findings

\begin{tabular}{|c|c|c|c|}
\hline & Project management & Value propositions & Knowledge practice \\
\hline $\begin{array}{l}\text { Client } \\
\text { expected } \\
\text { norms of } \\
\text { the hybrid } \\
\text { project } \\
\text { team } \\
\text { found in } \\
\text { the case } \\
\text { study }\end{array}$ & 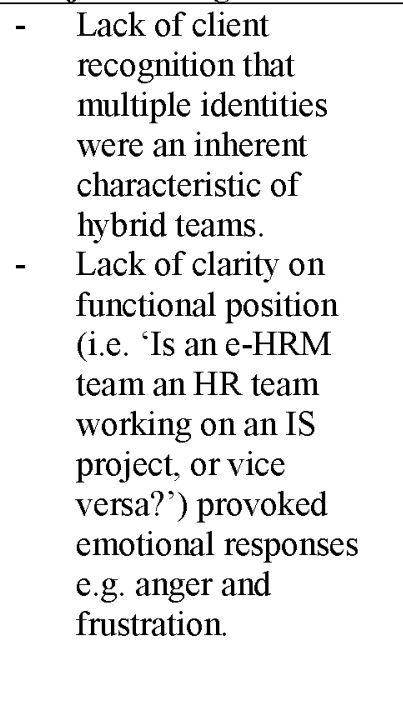 & $\begin{array}{l}\text { - Clients required team value } \\
\text { propositions to have a } \\
\text { direct match with their } \\
\text { expectations } \\
\text { The mismatch between } \\
\text { what the team promised and } \\
\text { what was expected by its } \\
\text { clients generated discord. } \\
\text { Perception that the team } \\
\text { lacked commitment, and } \\
\text { was taking advantage of } \\
\text { their hybrid position } \\
\text { An impression that the team } \\
\text { promises were more related } \\
\text { to IS protocols and policies } \\
\text { than the HR policy and } \\
\text { practice improvement } \\
\text { outcomes client expected. }\end{array}$ & $\begin{array}{l}\text { - Changing organisational } \\
\text { structures generated } \\
\text { associated changes in the } \\
\text { requirements for a team's } \\
\text { skills and knowledge } \\
\text { - Clients were greatly } \\
\text { dependent on, but also } \\
\text { constrained by the } \\
\text { knowledge practice of the } \\
\text { team } \\
\text { There was a general lack of } \\
\text { client knowledge about what } \\
\text { the team can offer } \\
\text { Clients did not know who to } \\
\text { ask when they encountered } \\
\text { problems }\end{array}$ \\
\hline $\begin{array}{l}\text { Hybrid } \\
\text { project } \\
\text { team } \\
\text { expected } \\
\text { norms of } \\
\text { themselves } \\
\text { found in } \\
\text { the case } \\
\text { study }\end{array}$ & 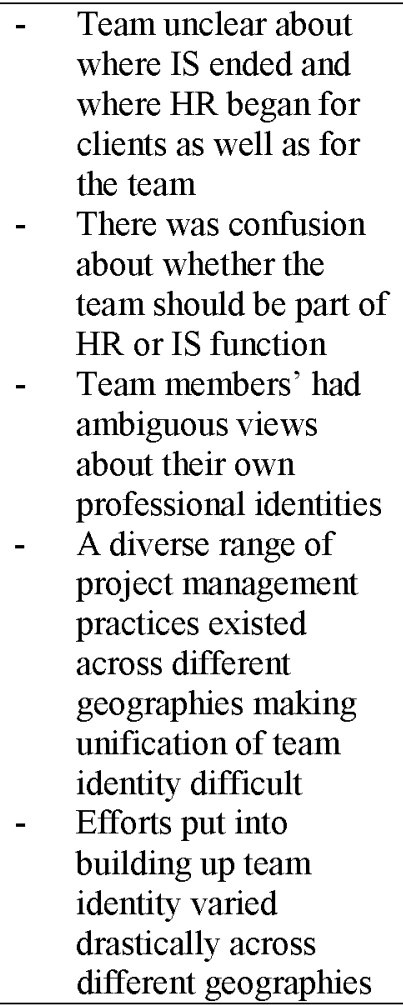 & $\begin{array}{l}\text { - It was hoped that } \\
\text { maximizing hybrid project } \\
\text { work would enable } \\
\text { enactment of an } \\
\text { organisation's strategic } \\
\text { intent } \\
\text { Also that HR capability } \\
\text { could be maximized } \\
\text { through integrated and } \\
\text { interactive technologies } \\
\text { Constant changes in } \\
\text { requirements created } \\
\text { uncertainty. } \\
\text { The way in which an } \\
\text { individual's role was } \\
\text { defined led to the } \\
\text { questioning of what } \\
\text { benefits they could expect } \\
\text { from being part of the team } \\
\text { Future career prospects } \\
\text { were affected when a } \\
\text { identity was poorly defined. }\end{array}$ & $\begin{array}{l}\text { - The team's knowledge base } \\
\text { evolved around individual } \\
\text { availability rather than } \\
\text { fulfilling client requirements } \\
\text { Better care could have been } \\
\text { taken in identifying clients' } \\
\text { growing dissatisfaction } \\
\text { towards the team } \\
\text { - Dual reporting lines created } \\
\text { identity ambiguity for the } \\
\text { team and others } \\
\text { Variation in knowledge } \\
\text { practice across different } \\
\text { geographies was an ongoing } \\
\text { issue } \\
\text { The team had a strong } \\
\text { perception that there was a } \\
\text { lack of appreciation of their } \\
\text { work by the organisation } \\
\text { A danger of becoming } \\
\text { 'Jack-of-all-trades and } \\
\text { master of none'. }\end{array}$ \\
\hline
\end{tabular}

We see in Table 4 the ways in which the functional and dysfunctional effects of hybridity play out in the relations between an e-HRM project team and its clients. In this case we see how project team members, whilst trying to maintain an 'aura of stability' (Whetton and Godfrey, 1998, p. 35), did not have a good sense of who they were as a global team. The dissatisfaction of the HR client resulted in their attempts at independently enacting their own IS capability, rather than through the e-HRM team in some occasions. 
Insight into the specifics of identity ambiguity and its role in hybrid project team activities begins with an understanding of the key dimensions: project team management, value propositions and knowledge practices, highlighting in particular the paradoxes evident in each (Clarke et al, 2009):

\section{Project team management and identity ambiguity}

A number of paradoxical outcomes of the project emerged as a result of the project team management endeavour. For example, the expected norms of clients about hybridity was that hybrid specialists make excellent candidates for boundary spanning roles (see Scarborough, 1993; Miller et al., 2008) and that the project team as a whole would both synthesize and cater for different functional needs, in this case HR and IS functions, which would otherwise be difficult to achieve through a conventional team arrangement. Thus the HR clients were expecting an HR solution to be implemented but were sorely disappointed as the project team majored primarily on providing IS solutions

The expected norms of the project team were related to role cohesiveness but with the diverse range of practice and structure across different geographies, the identity of the project team became extremely fragmented. As a result, some of the project team members were even questioning whether they actually belonged to HR or not, while many were wondering whether some parts of the project should indeed be carried by other providers. Overall, then, such a lack of consistency of the project team offering, structure and activities had created much identity ambiguity.

\section{Value propositions and identity ambiguity}

As we saw in Tables 1 and 2, a project team makes service promises to its clients through value propositions. A unique value proposition expressed in a relevant and differentiated way can provide clarity to its key audiences and result in the creation of preference and loyalty. However, as we saw in Table 4, clarity was sadly lacking when the client's expectations about the value propositions that the team should deliver were very different to the actual deliverables of the project team.

What is clear from our findings is that HR clients perceived a lack of commitment from the project team as the team appeared to take advantage of their dual positions to purposefully avoid tasks that they were expected to perform. By contrast, the project team saw their value propositions as being about getting the systems in place and running, and therefore felt it was more important to follow the protocol and policies set by their IS colleagues. The ambiguous nature of project team identity, then, emerges from a failure to define and agree the scope and scale of responsibility and accountability, both for individual team members as well as the team as a whole, and ensuring these are aligned with clients' needs. From the project team perspective, lack of clarity in project team identity definition also needs to be addressed in order to reduce concerns of individual team members not only about role performance expectations, but also in relation to potential impacts on their future career prospects.

\section{Knowledge practice and identity ambiguity}

From the perspective of knowledge practice, the problem was not only the general lack of understanding in terms of what knowledge, skills and capabilities the project team had, it was also the inconsistency reflected in the multiple identities which many HR clients associated with them. For example, one area of complaint by HR clients was that they did not know who to go to in order to get some of the systems problems sorted. Given that the team has evolved over time, its knowledge base has grown more on the basis of who is available to do team tasks, rather than 
who has the right expertise to add to the existing knowledge profile of the team. Many team members did not perceive the work carried out by the team as something valued by the business managers, therefore, it is perhaps understandable that some tried to explore different opportunities through which their expertise might be appreciated.

In synthesizing the three dimensions of the project team's identity ambiguity, what also becomes clear is the recursive occurrence of mismatches between the two perspectives of the project context, that is, the expected norms of the project team and what was expected by the team's clients.

\section{Recursive mismatching of expected norms and the dysfunctional effects of identity ambiguity}

As evidenced in this case study, the incompatibility between the norms of a hybrid e-HRM project team and the norm expectations of their HR clients can continuously and negatively impact on project lifecycle progression. We call this recursive mismatching and it can occur for a number of reasons. Firstly, it can occur when clients who have begun the project with a positive expectation of the service delivery benefits a hybrid team member can provide are continuously disappointed by a failure to deliver quality services. Secondly, it can occur when there is an over-orientation of the e-HRM project team towards IS-related rather than HR-related value propositions (promises). This mis-reading by project team members of their HR clients' actual needs invariably results in client expectations not being met. Thirdly, recursive mismatching and dysfunctional effects can occur when there is a lack of knowledge of clients about the knowledge resources they can draw upon from both individual team members and the project team as a whole. Finally, if the identity of the project team is not clearly defined by the team very early on or identity resolution not undertaken as soon as difficulties have arisen, identity ambiguity will just continue to develop. Therefore, as entangled and dysfunctional effects occur in the continuity and smoothness of project implementation, this can result in re-occurring client anger and frustration about project management of the team. We suggest that the longer the project life cycle, the more difficult it then becomes for each party to untangle such dysfunctional effects and this further aggravates identity ambiguity.

\section{CONCLUSIONS AND IMPLICATIONS}

In relation to our original statement that hybrid teams are not a panacea for a successful e-HRM project, our findings in this paper demonstrate how the interactions between a hybrid e-HRM project team and its clients can become a source of social identity ambiguity. In this we highlight the paradox that such a concept can both positively and negatively impact on working project relationships characterised by 'subjectively construed discursive identities ....that are both contingent and fragile' (Clarke et al., 2009, p323).

In this section we consider the lessons from this study and the implications for project team management practice in information systems of the e-HRM kind, as well as IS project team management generally. These lessons relate to how a project team might usefully focus not only on their social identity work in trying to ascertain 'who do we think we are?' but also on 'who do our clients think we are?'. Then, after taking their clients' views into account, they might also add onto this list of self-reflexive questions 'who do they think we should be?' and 'who do we think we should be?' (see Corley and Gioia, 2004, p. 176). It is in this reflexive process that discrepancies and alignments between the perspective of each party can be identified and decisions made about how to make sense of any discrepancies and the extent to which each is important or relevant (Chreim, 2002). It is also through this reflexive process that project team 
identity can be strengthened, ambiguity reduced and, we suggest, future project work progress with less relational difficulty.

This is not to say that such an activity will resolve all relational issues. As we have suggested in this paper, social identity work is essentially a temporary, changing activity but this does not discount that in practice at project team level there are at least three possible dimensions where the project team-client relationship can strengthen or flounder: project team management, value propositions and knowledge practice. Despite the fact that the three dimensions might not be exhaustive in terms of their conceptual coverage, they do provide a valuable set of intellectual guidelines to make sense of the diverse range of relevant perspectives and debates. Furthermore, our case and findings have provided an insightful elaboration of how these dimensions can be applied to make sense of a complex, ambiguous and emerging hybrid project team setting.

For example, from the clients' perspective the very enactment of project team relationships can induce identity ambiguity. There is the strong possibility that role fragmentation might result from the design of those hybrid roles. What can assist project team managers to understand the difficulties encountered in a lack of actualization of client expectations is to examine the influence of structure on project team value propositions and realise the power another function (e.g. IS) can have on this process. Clarification of such aspects provides the client with the potential to address client service issues for the long term.

In addition, given that identity ambiguity exists as a possible theme for interpretation across organisational phenomena (Feldman and March, 1981; Pondy et al., 1988, Martin and Meyerson, 1988, cited in Alvesson, 2001, p. 869), creating a value proposition is, we argue, an essential requirement for project team success. A project team value proposition comprises the promises and commitment a project team makes to their internal clients to deliver a package of relevant services and products which uniquely meets internal clients' needs. Creating a value proposition requires answers to particular contextual questions. For instance, who exactly is the client that the value propositions are being created for? Garnered from client feedback, what do clients say they value? A clear description is necessary of what is being offered to the clients in terms of product and/or service. What are the benefits to the client? What substitutes or alternatives are there? It needs to be made clear how the offering of the team is different from anything else being offered. Do client requirements cohere with organisational level requirements for the project? What evidence/proof do team members have that they can deliver what they promise?

The strength of project team identity depends on how well the team fulfils its promises and the consistency and clarity of how well these promises are communicated to clients. We contend that value propositions which are agreed with the clients of the project team are important to project team leaders to enable them to get the right level of attention, resources and support for their project staff in order that they, in turn, are able to address quality and ensure sustainability of internal client services. However, for projects such as e-HRM, it can be difficult to rally teams and support for what might be termed seemingly mundane projects which do not appear to offer breakthrough potential. The 'electronic filing cabinet' of employee information may not seem 'sexy', so can often be below the radar for executives who do not fully appreciate their potential power for human capital management. E-HRM teams are mainly 'invisible' as an occupational group (Williams et al, 2009) and few if any e-HRM project managers wield much clout. Many operate in authority vacuums where they have little or no formal control over the people on whom they must rely outside of their project teams to achieve project goals. What's more, project leaders, when they are able to rally teams, often focus too narrowly on the work to be done. In their preoccupation with task accomplishment, project leaders frequently overlook the 
importance of establishing, maintaining and communicating to key stakeholders a clear, consistent and unique message of the team's commitment to their stakeholders' requirements.

Overall, then, the practical value of our study is for those project team leaders who must sequence, time and articulate core messages about their projects to the right audiences. As we found, this requires that they give thought to their offering and also how their services and products are positioned with regard to the needs of their clients. In this endeavour, hybridness is a useful managerial concept for cross-functional projects. However, as we have extensively elaborated throughout our paper, hybrids should not be perceived as a panacea to the oftenunderestimated social and organisational problems that can characterise the interactions between project teams and their stakeholders. For as we have shown from our case study research, the design and deployment of hybridness needs to be approached with care, not least because of the potential for a gradual yet unanticipated build-up of identity ambiguity that is manifested by the magnitude of gaps and recursive mismatching of expected and enacted norms in the relations between the e-HRM project team and its clients.

\section{REFERENCES}

Albert, S. Whetten, D. A. 1985. Organizational identity. In L. L., Cummings \& B. M. Staw (Eds.), Research in organizational behaviour. 7, 263-295. JAI Press, Greenwich, CT.

Alvesson, M. 2010. Self-doubters, strugglers, storytellers, surfers and others: Images of selfidentities in organization studies. Human Relations. 63 2, 193-217.

Alvesson, M. 2001. Knowledge work: Ambiguity, image and identity. Human Relations. 54, 863-886.

Alvesson, M., Ashcraft, K.L., Thomas, R. 2008. Identity matters: Reflections on the construction of identity scholarship in organization studies. Organization. 15, 5-28.

Alvesson, M., Willmott, H. 2002. Identity regulation as organizational control: Producing the appropriate individual, Journal of Management Studies. 39, 619-44.

Ashforth, B.E. 1998. Becoming: How does the process of identification unfold?', in: Whetten, D., Godfrey, P. (Eds.), Identity in Organizations: Developing Theory through Conversations. Sage, Thousand Oaks, pp. 213-222.

Ashforth, B.E., Kreiner G.E., Fugate, M. 2000. All in a day's work: boundaries and micro role transitions. Academy of Management Review. 25, 472-491.

Ashforth, B.E., Mael, F. 1989. Social identity theory and the organization. Academy of Management Review. 14, 20-39.

Ahuja, M.K., Thatcher, J.B. 2005. Moving beyond intentions and towards the theory of trying: effects of work environment and gender on post-adoption information technology use. MIS Quarterly. 29, 427-459.

Beech, N. McInnes, P. 2005. Now where was I? Questioning assumptions of consistent identity in Pullen, A. \& Linstead, S. (Eds) Organization and Identity, London: Routledge. 
Bondarouk, T., Ruël, H. 2009. Electronic Human Resource management: Challenges in the digital era. International Journal of Human Resource Management. 20, 503-514.

Brown, A.D. and Lewis, M.A. 2011. Identities, discipline and routines. Organization Studies. 32, 871-895.

Brown, A.D., Humphreys, M., Gurney, P.M. 2005. Narrative, identity and change: A case study of Laskarina Holidays. Journal of Organizational Change Management. 18, 312-326.

Bryman A., Bell, E. 2003. Business Research Methods. Oxford University Press, Oxford.

Buckley, P., Minnette, K., Joy, D., Michaelis, J. 2004. The use of an automated employment recruiting and screening system for temporary professional employees: A case study. Human Resource Management. 43, 233-241.

Burke, P.J., Reitzes, D.C. 1981. The link between identity and role performance. Social Psychology Quarterly. 44, 83-92.

Cerulo, K. 1997. Identity construction: New issues, new directions. Annual Review of Sociology. 23, 385-409.

Chreim, S. 2002. Reducing dissonance: Closing the gap between projected and attributed identity, in: Moingeon, B., Soenen, G. (Eds.), Corporate and Organizational Identities: Integrating Strategy, Marketing, Communication, and Organizational perspectives. London: Routledge, London, pp. 75-90.

Cohen, S. Taylor, L. 1992. (originally 1978) Escape Attempts: The Theory And Practice Of Resistance To Everyday Life. Routledge, London.

CIPD 2005. People Management and Technology: Progress and Potential, London: CIPD.

Clarke, C.A., Brown, A. D., and Hailey, V.H. 2009. Working identities? Antagonistic discursive resources and managerial identity, Human Relations, 62, 323-352.

Cooke, F.L., Shen, J., Mcbride, A. 2005. Outsourcing HR as a competitive strategy? A literature review and an assessment of implications. Human Resource Management. 44, 413-432.

Corley, K.G., Gioia, D.A. 2004. Identity ambiguity and change in the wake of a corporate spinoff. Administrative Science Quarterly. 49, 173-208.

Davis, F. 1989. Perceived usefulness, perceived ease of use, and user acceptance of information technology. MIS Quarterly. 13, 319-340.

Davis, F. 1993. User acceptance of information technology: system characteristics, user perceptions and behavioural impacts. International Journal of Man-Machine Studies. 38, $475-$ 487.

Denzin, N. 1997. The Research Act. Prentice Hall, New Jersey. 
Dutton, J.E., Roberts, L.M., Bednar, J. 2010. Pathways for positive identity construction at work: four types of positive identity and the building of social resources. Academy of Management Review. 35, 265-293.

Eagly, A.E., Chin, J.L. 2010. Diversity and leadership in a changing world. American Psychologist. 65, 216-224.

Elias, A., Cavan, R., Jackson, L.S. 2002. Stakeholders analysis for R\&D project management. R\&D Management. 32, 301-310.

Eppler, M.J., Sukowski, O. 2000. Managing team knowledge: core processes, tools and enabling factors. European Management Journal. 18, 334-341.

Erikson, E. 1974. Identity, Youth and Crisis. Faber and Faber, London.

Ettenson, R. Knowles, J. 2008. Don't confuse reputation with branding. MIT Sloan Management Review. Winter, 49, 19-21.

Feldman, M., March, J. 1981. Information in organizations as signal and symbol. Administrative Science Quarterly. 26, 171-86.

Fiol, C.M. 2001. Revisiting an identity-based view of sustainable competitive advantage. Journal of Management. 27, 691-699.

Florkowski, G., Olivas-Lujan, M. 2006. The diffusion of human resource information technology innovations in US and non-US firms. Personnel Review. 35, 684-710.

Forster, N. 1994. The analysis of company documentation, in: Cassell, C., Symon, G. (Eds.), Qualitative Methods in Organizational Research. Sage, Thousand Oaks, 147-166.

Fournier, V. 1999. The appeal to professionalism as a disciplinary mechanism. Sociological Review. 47, 280-307.

Gann, D. M. Salter, A. J. 2000. Innovation in project-based, service-enhanced firms: the construction of complex products and systems. Research Policy. 29, 955-972.

Gardner, S., Lepak, D., Bartel, K. 2003. Virtual HR: The impact of information technology on the human resource professional. Journal of Vocational Behavior. 63, 159-179.

Gergen, K.J. 1994. Realities and Relationships: Soundings in Social Construction. Harvard University Press, Boston.

Gioia, D. A. Schultz, M. Corley, K. G. 2000. Organizational identity, image and adaptive instability. Academy of Management Review. 25. 1, 63-81.

Habermas, J. 1972. Knowledge and Human Interests. Heinemann, London.

Haslam, S. A. 2001. Psychology in Organizations: The Social Identity Approach. Sage, London. 
Haslam, S.A., Postmes, T., Ellemers, N. 2003. More than a metaphor: Organizational identity makes organizational life possible. British Journal of Management. 14, 357-369.

Hawking, P., Stein, A., Foster, S. 2004. E-HR and employee self-service: A case study. Information Science and Information Technology Conference, Rockhampton.

Ivory, C.J., Alderman, N., Thwaites, A., McLoughlin, I., Vaughan, R. 2007. Working around the barriers to creating and sharing knowledge in capital goods projects: the client's perspective. British Journal of Management. 18, $224-240$.

Jacobs, K. 2005. Hybridisation or polarisation: Doctors and accounting in the UK, Germany and Italy. Financial Accountability \& Management. 21, 35-162.

Kärreman, D., Alvesson, M. 2001. Making newsmakers: Conversational identity at work. Organization Studies. 22, 59-89.

Kim, S.S., Son, J-Y. 2009. Out of dedication or constraint? A dual model of post-adoption phenomena and its empirical test in the context of online services. MIS Quarterly. 33, 49-70.

Klein, H., Myers, M. 1999. A set of principles for conducting and evaluating interpretive field studies in information systems. MIS Quarterly. 23, 67-94

Kogut, B., Zander, U. 1996. What firms do? Coordination, identity, and learning. Organization Science. 7, 502-518.

Kurunmäki, L. 2004. A hybrid profession- the acquisition of management accounting expertise by medical professionals. Accounting, Organizations \& Society. 29, 327-347.

Larson, M. and Wikström, E. 2007. Relational interaction processes in project networks: the consent and negotiation perspectives. Scandinavian Journal of Management, 23,327-352

Lederer, A.L., Gardiner,V. 1992. The process of strategic information planning. Journal of Strategic Information Systems. 1, 76-83.

Lepak, D., Snell, S. 1998. Virtual HR: Strategic human resource management in the $21^{\text {st }}$ century. Human Resource Management Review. 8, 215-234.

Lincoln, Y.S., Guba, E. 1985. Naturalistic Inquiry. Sage, Thousand Oaks.

Lincoln, Y.S., Denzin, N.K. 1994. Handbook of Qualitative Research. Sage, Thousand Oaks.

Oakes, P.J., Turner, J.C., Haslam, S.A. 1991. Perceiving people as group members: The role of fit in the salience of social categorizations. British Journal of Social Psychology. 30, 125-144.

Marler, J. 2009. Making human resources strategic by going to the Net: reality or myth? International Journal of Human Resource Management. 20, 515-527.

Martin, J., Meyerson, D. 1988. Organizational cultures and the denial, channelling and acknowledgement of ambiguity, in Pondy, L., Boland, R., Thomas, H. (Eds.), Managing Ambiguity and Change. Wiley, New York, 93-126. 
McDermott, R. (1976) 'Making Sense and Feeling Good: The Ethnography of Communication and Identity Work', Communication 2, 121-42.

Miller, P., Kurunmäki, L., O'Leary, T. 2008. Accounting, hybrids and the management of risk. Accounting, Organizations and Society. 33, 942-967.

Morris, T., Empson, L. 1998. Organization and expertise: An exploration of knowledge bases and the management of accounting and consulting firms. Accounting, Organizations and Society. $23,609-624$

Musson, G. and Duberley, J. 2007. 'Change, Change or Be Exchanged: The Discourse of Participation and the Manufacture of Identity', Journal of Management Studies 44. 1, 143-64.

Nach, H., Lejeune, A. 2010. Coping with information technology challenges to identity: A theoretical framework. Computers in Human Behavior. 26, 618-629.

Newell, S., Robertson, M., Scarbrough, Swan, J. 2002. Managing Knowledge Work. Palgrave, Hampshire

Newell, S., Tansley, C., Huang, J. 2004. Social capital and knowledge integration in an ERP project team: The importance of bridging and bonding. British Journal of Management. $15,43-57$.

Newell, S., Tansley, C., Wagner, E. 2008. The liminality associated with project teams: exploring and explaining some of the problems of enterprise system project implementations. 16th European Conference on Information Systems. University of Galway, Ireland.

Oakes, P.J., Turner, J.C., Haslam, S.A. 1991. Perceiving people as group members: The role of fit in the salience of social categorizations. British Journal of Social Psychology. 30, 125-144.

Pan, S-L., Tan, B. 2011. Demystifying case research: A structured-pragmatic-situational (SPS) approach to conducting case studies. Information \& Organization. 21, 161-176.

Pondy L., Boland, R., Thomas, H. 1988. Managing Ambiguity and Change. Wiley, New York.

Pullen, A. 2006. Managing Identity. Palgrave Macmillan: Basingstoke.

Pullen, A. Linstead, S. (Eds). 2005. Organization and Identity. Routledge, London.

Rees, W.D. 1996. The importance of the managerial hybrid. Industrial \& Commercial Training. $28,5-9$.

Ruel, H., Bondarouk, T., Looise, J. 2004. E-HRM: innovation or irritation. An explorative empirical study in five large companies on web-based HRM. Management Revue, 15, 364-381.

Ruel, H., Bondarouk, T., Van der Velde, M. 2007. The contribution of e-HRM to HRM effectiveness. Employee Relations, 29, 280-291. 
Ruta, C. 2005. The application of change management theory to HR portal implementation in subsidiaries of multinational corporations. Human Resource Management. 44, 35-53.

Scarbrough, H. 1993. Problem-solving solutions in the management of information systems expertise. Journal of Management Studies. 30, 939-955.

Schulz, M. Hatch, M.J. Larsen, M. H. (Eds) 2000. The Expressive Organization: Linking Identity, Reputation, and the Corporate Brand. Oxford University Press, Oxford.

Snell, S., Stueber, D., Lepak, D. 2002. Virtual HR departments: Getting out of the middle, in Henneman, R.; Greenberger, D. (Eds.), Human Resource Management in Virtual Organizations. Information Age Publishing, Greenwich, CT, 81-102.

Söderlund, J. 2011. Pluralism in project management: Navigating the crossroads of specialization and fragmentation. International Journal of Management Reviews. 13, 153-176.

Stewart, P. J. Strathern, A. J. (Eds) 2000. Identity Work: Constructing Pacific Lives. University of Pittsburgh Press, Pittsburgh, PA.

Storey, J., Salaman, G. Platman, K. 2005. Living with Enterprise in an Enterprise Economy: Freelance and Contract Workers in the Media. Human Relations 58. 8, 1033-54.

Strohmeier, S. 2007. Research in e-HRM: review and implications. Human Resource Management Review. 17, 19-37.

Stroehmeier, S. 2009. Concepts of e-HRM consequences: a categorisation, review and suggestion, International Journal of Human Resource Management. 20, 528-543.

Sveningsson, S. Alvesson, M. 2003. Managing Managerial Identities:Organizational Fragmentation, Discourse and Identity Struggle. Human Relations 56. 10, 1163-93.

Tajfel, H., Turner, J.C. 1979. An integrative theory of intergroup conflict, in Austin, W.G., Worchel, S. (Eds.), The Social Psychology of Group Relations. Brooks-Cole, Monterey, 33-47.

Thite, M., Kavanagh, M. 2009. Evolution of human resource management and human resource information systems: The role of information technology, in Kavanagh, M., Thite, M. (Eds.), Human Resource Information Systems: Basics, Applications and Future Directions. Sage, Thousand Oaks, 3-24.

Tansley, C., Newell, S. 2007a. A knowledge-based view of agenda-formation in the development of human resource information systems. Management Learning. 38, 95-119

Tansley, C., Newell, S. 2007b. Project team social capital, leadership and trust in HR project managers' knowledge in human resourcing information systems projects. Journal of Managerial Psychology. 22, 350-368.

Tansley, C, Newell, S., Williams, H. 2001. Effecting HRM-style practices through an integrated human resource information system: An e-greenfield site? Personnel Review. 30, 351-371. 
Thomas, R., Davies, A. 2005. Theorising the micro-politics of resistance: Discourses of change and professional identities in the UK public services. Organization Studies. 26, 683-706.

Ulrich, D. 1996. Human Resource Champions. Harvard Business School Press, Boston.

van Knippenberg, D., van Knippenberg, B., De Cremer, D., Hogg, M.A. 2004. Leadership, self, and identity: A review and research agenda. Leadership Quarterly. 15, 825-856.

van Knippenberg, D., van Knippenberg, B., Monden, L., de Lima, F. 2002. Organizational identification after a merger: A social identity perspective. British Journal of Social Psychology. $41,233-252$.

Walsham, G. 1995. The emergence of interpretivism in IS research. Information Systems Research. 6, 376-394.

Watson, T. 2008. Managing Identity: Identity Work, Personal Predicaments and Structural Circumstances. Organization 15. 1, 121-43.

Watson, T. J (2001) In Search of Management, revised edn. London: Thomson Learning (originally Routledge, 1994).

Webb, J. 2006. Organizations, Identities and the Self. Palgrave, Hampshire.

Webb, E., Weick, K.E. 1979. Unobtrusive measures in organizational theory: A reminder. Administrative Science Quarterly. 24, 650-659.

Weick, K.E. 1995. Sensemaking in Organizations. Sage, Thousand Oaks.

Wetherell, M. Mohanty, C. T. 2010. The Sage Handbook of Identities. Sage, London.

Whetton, D.A., Godfrey, P. 1998. Identity in Organizations- Developing Theory through Conversations. Sage, Thousand Oaks.

Williams, H., Tansley, C., \& Foster, C. (2009). HRIS Project Teams Skills and Knowledge: A Human Capital Analysis. In T. V. Bondarouk, H. J. M. Ruël, K. Guiderdoni-Jourdain \& E. Oiry (Eds.), Handbook of Research on E-Transformation and Human Resources Management Technologies: Organizational Outcomes and Challenges (pp. 135-152). Information Science Reference, London.

Willem, A., Scarbrough, H., Buelens, M. 2007. Impact of coherent versus multiple identities on knowledge integration. Working paper reference: May 2007/464 D/2007/7012/35. Faculteit economie En bedrijfskunde, Tweekerkenstraat 2, B-9000 Gent.

Ybema, S., Keenoy, T., Oswick, C., Beverungen, A., Ellis, N., Sabelis, I. 2009 Articulating identities. Human Relations, 62 3: 299-322. 